\title{
The Effect of Conan Discovery Learning Model on Citizenship Education Learning Motivation in Middle Schools
}

\author{
Vinni Dini Pratiwi ${ }^{1}$ and Mukhamad Murdiono ${ }^{2}$ \\ ${ }^{1}$ Civic Education, PostgraduateStudent, Universitas Negeri Yogyakarta, Indonesia \\ ${ }^{2}$ Doctor, Department of Civic Education, Universitas Negeri Yogyakarta, Indonesia \\ ${ }^{1}$ vinnidini.2018@student.uny.ac.id, ${ }^{2}$ mukhamad murdiono@uny.ac.id
}

\begin{abstract}
This study aims to analyze student motivation through the Conan Discovery Learning model. This model combines the models of inquiry learning, discovery, and animation Conan. The use of discovery learning models and inquiry learning models can change the way teachers see teaching in the classroom by using Conan's discovery learning. Conan's discovery learning model in this study proposes that students become Conan's detectives and look for rules that apply in the environment around students. The method in this study uses quantitative methods with the Quasi-Experimental Design method with data collection techniques using questionnaires and observations. The data analysis technique used the "t" test with the help of the SPSS 16 program. In this design, the researcher held a direct discussion about one group of subjects with two conditions carried out without a comparison group, so that each subject was a control class that had its class. The results of the study showed a significant difference between the discussion before using the Conan discovery learning model and the handling after the Conan discovery learning model. The difference means that completion after studying Conan's findings is better than treatment before Conan's discovery learning model.
\end{abstract}

Keywords: Conan, Discovery learning, Inquiry inquiry, and learning motivation

\section{INTRODUCTION}

Learning activities that involve students in simple research-based assignments mean that they have used higher-order thinking skills. The fundamental approach to learning is when an educator might think of low-level thinking, remember facts, and memorize concepts. Thus, education becomes the act of depositing or students passively adapting to the world and the fragmented or distorted view of reality stored in it [1]. Students rarely get the opportunity at school to practice history by systematically investigating traces of evidence, reading key source documents, doing extensive research, and drawing their conclusions for interpretation and the arguments they produce for consideration among their peers [2].

The use of discovery learning models and inquiry learning models can change the way teachers look at teaching in the classroom. It does not have to be agreed with the Learning Implementation Plan (RPP) used. The success of class mastery for teachers is the teacher's understanding of the characteristics of students. At the beginning of the learning model, the 
author unites this second model with the name of learning the invention of Conan because it was inspired by the cartoon movie "Detective Conan". Based on this, the authors named this model the name of the discovery learning Conan (Conan Discovery Learning) in the hope that students would be more active and creative in developing special knowledge material in PPKn lessons.

Inquiry-based instruction is a pedagogical strategy that places teachers as facilitators and students who encourage critical thinking in building knowledge that is understood [3]. Students push to build new constructions about their past, incoming knowledge, and information, using their intuition, creativity, creativity, and curiosity towards new information. Inquiry students gain confidence in their scientific abilities [4]. The investigation gives children opportunities to develop complementary skills such as working in groups, improving themselves textually and verbally, and improving open problem solving and other crossdisciplinary skills [5].

Using the learning discovery model, which is one of the various models considered in which students are active and mentored by teachers, is considered to improve student and inquiry learning skills more than traditional supportive methods [6]. This model officially rejects what has been agreed or read, and is approved by actively responding to and solving any problems. The discovery learning model is a learning model that encourages student activities in learning. This model encourages students to learn on their own [7]. Searching for learning as an active learning style in which students are actively involved to participate with Environmental Assistance, manipulate objects, grapple with questions and controversies, and conduct experiments today is also supported by existing theories [8].

This model is structured based on cognitive theories that are issued in what happens in the mind compile receiving new information [9]. This second model can increase student motivation. Motivation to choose as a prerequisite and element needed for students in learning. All students in learning not only have the same goals but also have facilities for students who achieve good academic results because this is the most important because it can increase student academic achievement higher in the world [10].

Motivation is a very important factor in developing academic motivation. The quality of interaction between teacher and students and between academic groups (classmates) is balanced by many dimensions of extrinsic motivation [11]. Lack of motivation in education can damage their learning process. These different types of motivation produce different effects on student learning [12]. In the aspect of motivation, the teacher's role in the education process is to create challenges and positive attitudes that encourage learning and achieve their success. While students are processing qualitative and active knowledge to improve their academics [13].

Based on the explanation above, this paper aims to determine the effect of the Conan discovery learning model on learning motivation in citizenship education learning. The benefits of this writing are to increase knowledge and bring an understanding of the study model of "Conan Discovery Learning".

Citizenship education, in this case, plays an important role to teach young students about the education needed to support and utilize the knowledge needed to help in the growth and prosperity of their country [14].

\section{METHOD}

In this study using a quantitative approach with quasi-experimental methods. Quantitative researchers are phenomena by collecting numerical data which are analyzed using mathematical (statistical) methods [15]. This study uses a Quasi-Experimental Design 
method with data analysis techniques using the " $t$ " test with the help of the SPSS 16 program and data collection techniques using questionnaires and observations. In this design, the researcher makes direct observations of one group of subjects with two conditions carried out without a comparison group, so that each subject is a class of control over himself.

Categorizing the motivational variables in class VIII students in junior high school, the intervals used were: students' learning motivation data had 30 items with a score of 1-5. Maximum score $(30 \times 5)=150$, and minimum score $(30 \times 1)=30$ with the following intervals:

$$
\begin{gathered}
\mathrm{i}=\frac{\text { Maximum score }- \text { Minimum score }}{\text { Category }} \\
\mathrm{i}=\frac{150-30}{5} \\
\mathrm{i}=24
\end{gathered}
$$

Table 1. Student Motivation Intervals

\begin{tabular}{cl}
\hline Category & Classification \\
\hline Always & $\geq 126-150$ \\
Often & $\geq 102-126$ \\
Sometimes & $\leq 78-102$ \\
Rarely & $\leq 54-78$ \\
Never & $\leq 30-54$ \\
\hline
\end{tabular}

\section{RESULT AND DISCUSSION}

\subsection{Result}

\subsubsection{Conan}

Shinichi Kudo, a 17 years old high school detective who usually helps police solve cases. To hide his identityhe disguised his name as Conan Edogawa. Detective Conan is a detective manga series written and drawn by Gōshō Aoyama. Since 1994 this story has been published in Weekly Shōnen Sunday, published in Japan. Adapted in the television animation series produced by TMS Entertainment and the Japanese Yomiuri Telecasting Corporation, and is still airing today.

Detective Conan is an example of a character in a comic who has a clever, conscientious character, and does not give up easily. Because it is very idolizing for the character, children usually also learn to imitate everything that is done by the characters in comics in real life [16]. Conan was originally a high school student who likes to conduct criminal investigations. In one case Conan was given a drug that made his teenage body turn into a kindergarten boy's body so that in the next story, Conan continued to investigate like a detective. The difference, Conan is not as a teenage detective but as a detective of children with friends who are still in kindergarten. Many children's detective stories use onomatopoeia, such as brakes, books, digits, or other imitation sounds, making it easier for readers to understand Conan's story.

\subsubsection{The Conan Discovery Learning model of learning motivation for Pancasila Education and Citizenship}

The similarity between the Discovery Learning model and the Inquiry Learning model mainly establishes the need for critical thinking, engaging directly in learning which in turn will trigger students to produce many questions or statements. The discovery learning and inquiry learning model is a series of learning activities that involve the maximum ability of all students to search and investigate systematically, critically, and logically so that they can find their knowledge, attitudes, and skills as a form of behavior change [17]. 
This model can change the lecture method that applies to the curriculum by inviting students to be more active in the learning process. In the innovation model "Conan Discovery Learning", the writer chooses at the junior high school. The learning material applied in this study is "Showing Attitudes by Laws and Regulations" which includes an understanding of legal principles and legal behavior. The learning model with a scientific approach uses the Conan discovery learning model and with lecture, question and answer, discussion, and assignment methods. Tools/media and materials used in the form of LCD projectors, videos, laptops. Using teacher learning resources and student books for citizenship education in class VIII of junior high school, 2013 Curriculum, and Law Number 12 of 2011 concerning Formation of Regulations, and Undang-undang Negara Republik Indonesia Tahun 1945.

After treatment using Conan's discovery learning, students can: 1) describe the habit of complying with regulations in various environments; 2) explain the orderly traffic behavior; 3 ) practice the practice of complying with regulations in various environments; 4) presents a report on the results of an orderly traffic behavior study.

To obtain data on the influence of the Conan discovery learning model, learning motivation in learning citizenship education can be obtained through the results of a questionnaire that has been given by 34 students. The questionnaire was given before and after the application of the Conan discovery learning model. This learning motivation questionnaire consisted of 30 question items with 20 positive question items and 10 negative question items. Each question is accompanied by 5 alternative answers with a score of 5, 4, 3, 2, and 1 for positive question items, while for negative questions $1,2,3,4$, and 5 for questions that are not answered given a score of 0 , both questions positive or negative.

\subsubsection{The Effect of Conan Discovery Learning model of learning the motivation for Civic Education}

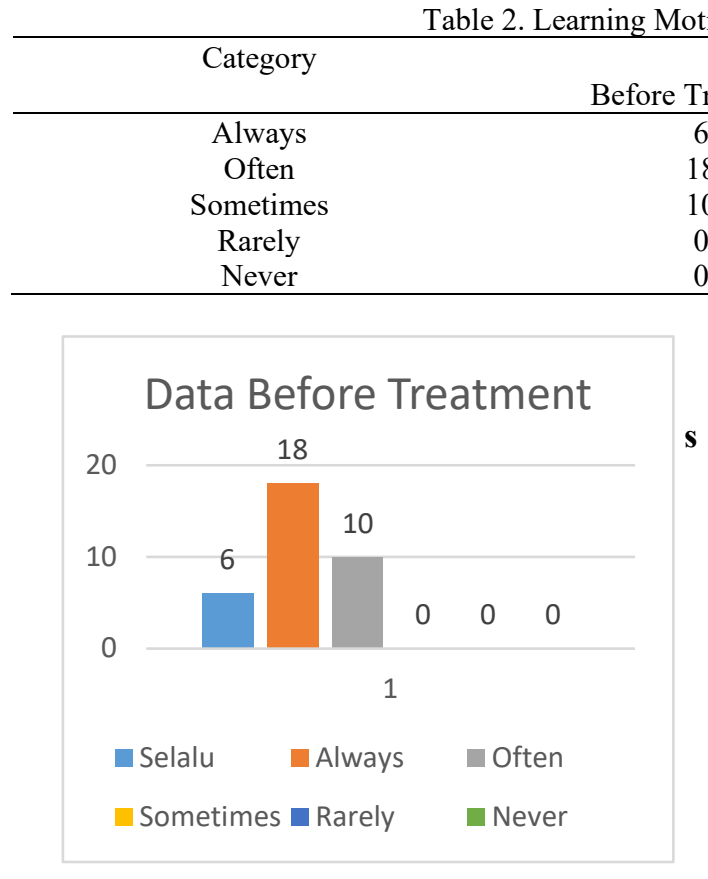

Figure 1. Motivation Diagram Before

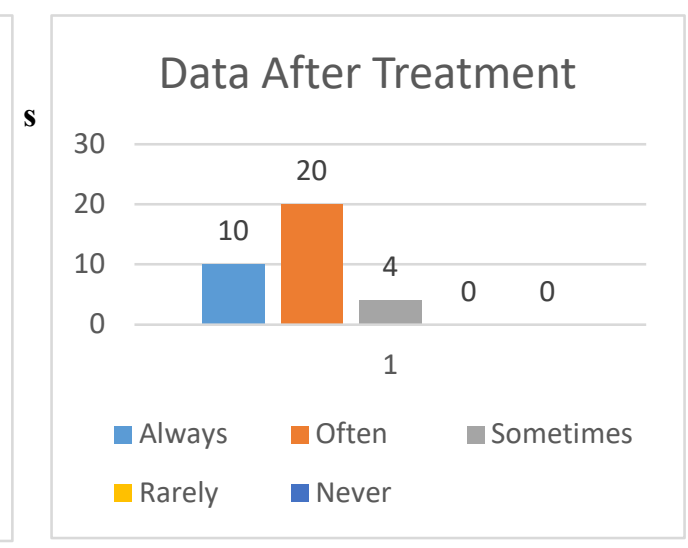

Figure 2. Motivation Diagram After 
Table 3. Paired Samples Statistics

\begin{tabular}{lcccc}
\hline Pair 1 & Mean & N & Std. Deviation & Std. Error Mean \\
\hline Sebelum Perlakuan & 111.82 & 34 & 15.708 & 2.694 \\
Sesudah Perlakuan & 118.88 & 34 & 18.521 & 3.176 \\
\hline
\end{tabular}

\section{Output Paired Samples Statistics}

This output shows the mean after treatment 118.88 and the mean before treatment 111.82,while $\mathrm{N}$ for each cell is 34. Standard devised for after treatment 18.521, and Standard revised for before treatment 15.708. The mean standard error for after treatment is 3.176, while for before treatment is 2.694 .

Table 4. Paired Samples Correlations

\begin{tabular}{cccc}
\hline \multicolumn{1}{c}{ Pair 1 } & N & Correlation & Sig. \\
\hline $\begin{array}{l}\text { Sebelum perlakuan dan } \\
\text { Sesudah Perlakuan }\end{array}$ & 34 & 0.298 & 0.087 \\
\hline
\end{tabular}

\section{Output Paired Samples Correlation}

This output displays the magnitude of the correlation between the two samples, where the visible correlation numbers are both 0.298 and the significance value 0.087 . Decision making is based on the results of the probability obtained, namely:

a. If the probability is $>0.05$ then the null hypothesis is accepted.

b. If the probability is $<0.05$ then the null hypothesis is rejected.

The magnitude of the significance value of 0.87 is far greater than 0.05 . Means the hypothesis that there is no relationship between the Conan discovery learning model of learning motivation is accepted,in other words between the Conan discovery learning model of learning motivation has a relationship.

Table 5. Paired Samples Test

\begin{tabular}{|c|c|c|c|c|c|c|c|c|}
\hline \multicolumn{9}{|c|}{ Paired Differences } \\
\hline \multirow[b]{2}{*}{ Pair 1} & & & & $\begin{array}{r}95 \% \mathrm{C} \\
\text { Interv } \\
\text { Diff }\end{array}$ & $\begin{array}{l}\text { idence } \\
\text { of the } \\
\text { nce }\end{array}$ & $\mathrm{t}$ & df & Sig (2- \\
\hline & Mean & $\begin{array}{c}\text { Std. } \\
\text { Deviation }\end{array}$ & $\begin{array}{l}\text { Std. } \\
\text { Error } \\
\text { Mean }\end{array}$ & Lower & Upper & & & tailed) \\
\hline $\begin{array}{l}\text { Sebelum Perlakuan- } \\
\text { Sesudah Perlakuan }\end{array}$ & -7.059 & 20.411 & 3.500 & -14.181 & .063 & -2.017 & 33 & .052 \\
\hline
\end{tabular}

\section{Output Paired Sample Test}

This output displays the results of a comparative analysis using the t-test. the output shows the mean after treatment and before treatment is -7.0 , the standard deviation is 20.411 , the mean standard error is 3.500 . The lowest difference is -14.182 , while the highest difference is 0.063 . Test results t-test $=-2.017$ with $\mathrm{df}=33$ and significance 0.052 .

\subsection{Discussion}

Based on the results obtained in the study, the Conan Discovery Learning model can increase motivation in learning citizenship education.

a. By referring to the value of the $t$-test by comparing $t_{o}$ ( $t$ observation) with $t_{t}(t$ table), wherewith $\mathrm{df}=33$ the numbers are obtained: 2.03 for the significant level of $5 \%$ and 2.74 for the significant level of $1 \%$. With $\mathrm{t}_{\mathrm{o}}=-2.017$ means greater than $\mathrm{tt}$ at the 
significant level of $5 \%$ and at a significant level of $1 \%(2.03<-2.017>2.74)$ which means the null hypothesis is rejected.

b. By referring to the amount of significance. In this case, the decision is taken with the provisions

- If the probability is $>0.05$ then the null hypothesis is accepted.

- If the probability is $<0.05$ then the null hypothesis is rejected.

At the significance level of 0.052 , it means that it is greater than 0.05 , it means that the null hypothesis states that there are differences before the treatment and after the treatment is received. There is a significant difference between the treatment before using the Conan discovery learning model and the treatment after the Conan discovery learning model. The mean difference shows that the treatment after the Conan discovery learning model is better than the treatment before the Conan discovery learning model.

The author tries to integrate the inquiry learning model with the discovery learning model to help students understand the material provided, especially in the citizenship education learning provided by the teacher. The author is inspired by the cartoon "Detective Conan." The author makes this combined model with the name of the discovery of learning Conan (Conan Discovery Learning). This model makes it easy for students to be more active and creative. This model is implemented by dividing groups and doing small research [18].

\section{CONCLUSION}

The results showed a significant difference between the discussion before using the Conan discovery learning model and the handling after the Conan discovery learning model. The difference means that completion after studying Conan's findings is better than treatment before Conan's discovery learning model.The "Conan Discovery Learning" model corresponds to citizenship education learning on the material "Demonstrating Attitude by Law and Regulation" in grade VIII of junior high school level. This learning model innovation is appropriate enough to build student motivation in learning material. Teachers can use this model innovation with small research conducted by students. The implementation of the "Conan Discovery Learning" innovation model is more active for students and teachers only as facilitators. The steps in this small study are also easy namely investigating the rules at school, group organizations, rules in the area of student residence, rules on traffic, and other places that are easily accessed and investigated by students. When teachers apply this innovation model, students are more active in learning citizenship education.

\section{REFERENCES}

[1]. P. Freire.Cultural Action For Freedom. Massachusetts: Harvard Educational Review and Center for study or development and social change, 1970.

[2]. B. Vansledright. "In Search of America's Past: Learning to Read History in Elementary School". New York: Teacher College Press, Vol. 2, pp. 10-11, 2002.

[3]. H. McBride, and L. Flagg. "What is a Community?: A First Grade Civics Lesson Plan Utilizing Inquiry-Based Instruction”.The Georgia Social Studies Journal, Vol. 2, No. 1, 2012.

[4]. C. Gormally, P. Brickman, B. Haller, andN. Armstrong. "Effects of Inquiry-based Learning on Students" Science Literacy Skills and Confidence". Ijsotl, Vol. 3 No. 2, 2009. 
[5]. M. R. Ariza, A.M. Abril, A. Quesada, and F.J. Garcia. "Bridging Inquiry-Based Learning and Science Education on Socio Scientific Issues: Contributions to The Parrise European Project". Inted, Vol. 10, No. 12, 2014.

[6]. A. G. Balim. "The Effects of Discovery Learning on Students'Success and Inquiry Learning Skills". Eurasian Research, Vol. 35, 2009.

[7]. R. E. Slavin. Cooperative learning. Bandung: Nusa Media, 2014.

[8]. R. G. Brown. Lecture notes dermatology. Jakarta: Erlangga. 2005

[9]. Svinicki. New Directions in Learning And Motivation. Jossey-Bass Publisher, 1999.

[10]. S. Saeed, and D. Zyngier. "How Motivation Influences Student Engagement: A Qualitative Case Study". Journal of Education and Learning, Vol. 1, No. 2, 2012.

[11]. G. Panisoara, N. Duta, and I. Panisoara. "The influence of reasons approving on student motivation forlearning". Procedia, Vol. 197, pp. 1215-1222, 2015.

[12]. J. Vibulphol. "Students 'Motivation and Learning and Teachers' Motivational Strategies in English Classrooms in Thailand". English Language Teaching, Vol. 9, No. 4, 2016.

[13]. E. Vero, and E. Puka. "The Importance of Motivation in an Educational Environment". Formazione \& Insegnamento, Vol. 17, No. 1, 2017

[14]. A. Bilal,and R. K. M. Szabis. "Citizenship Education in Pakistan". IISTE, Vol. 4, No. 16, 2014.

[15]. M. Aliaga, and B. Gunderson. Interactive Statistics. [Thousand Oaks]: Sage Publications, 2002.

[16]. A. Ulfah. Komik Pembelajaran: Sebuah Media Untuk Membangun Literasi Siswa Sekolah Dasar. Yogyakarta:Universitas Ahmad Dahlan, 2016.

[17]. Hanafiah and Suhana. Konsep strategi pembelajaran. Bandung: Refika Aditama, 2012.

[18]. K. Saddhono, A. Amalia, I. K. Sudarsana, and A. Indahingwati, "Multimedia Use For Beginner Level of Teaching Languages For Deaf Children: Study in Special Schools in Surakarta," in Journal of Physics: Conference Series, 2019, vol. 1254, no. 1, p. 12060. 